\title{
UNEXPECTED DISCOVERY OF A FUNNEL BEAKER CULTURE FEATURE AT THE KRAKÓW SPADZISTA (KRAKÓW-ZWIERZYNIEC 4) SITE
}

\author{
Jarosław Wilczyński ${ }^{1}$, MareK NowaK ${ }^{2}$, Aldona Mueller-BienieK ${ }^{3}$, \\ Magda KaPCia ${ }^{3}$, Magdalena Moskal-del HoYo $^{3}$
}

A u t h o r s' a d d r e s s e s: 1 - Institute of Systematics and Evolution of Animals, Polish Academy of Sciences, Sławkowska 17, 31-016 Kraków, Poland, e-mail: jaslov@wp.pl, ORCID: 0000-0002-97860693; 2 - Institute of Archaeology, Jagiellonian University, Gołębia 11, 31-007 Kraków, Poland, e-mail (corresponding author): mniauj@uj.edu.pl, ORCID: 0000-0001-7220-6495; 3 - W. Szafer Institute of Botany, Polish Academy of Sciences, Lubicz 46, 31-512 Kraków, Poland; A. Mueller-Bieniek, e-mail: a.mueller@, botany.pl, ORCID: 0000-0002-5330-4580; M. Kapcia, e-mail: m.kapcia@botany.pl, ORCID: 0000-00017117-6108; M. Moskal-del Hoyo, e-mail: m.moskal@botany.pl, ORCID: 0000-0003-3632-7227

A b s t r a c t. The paper presents a Neolithic feature discovered in trench $\mathrm{G}$ of the widely-known Paleolithic Gravettian site at Kraków Spadzista. Pottery and lithic artefacts as well as archaeobotanical data and radiocarbon dates demonstrate the existence of a stable human occupation with an agricultural economy. Due to the small number of distinctive fragments of pottery, both the Wyciąże-Złotniki group and the Funnel Beaker culture have to be taken into account in the discussion on the cultural attribution of the feature. The obtained absolute dates make a connection with the latter unit more probable.

K e y w o r d s: Kraków Spadzista, Neolithic, pottery, lithics, archaeobotany

\section{INTRODUCTION}

\section{Location of the site}

Kraków Spadzista site is located on the high northern headland of Sikornik, a twopeaked hill in the eastern part of the Sowiniec Range in Kraków measuring over $3 \mathrm{~km}$ in length (Fig. 1). The vast central part of Sikornik has revealed traces of Upper Palaeolithic occupation, while the south-western part gently passes through a severaldozen meter wide neck to the top part of the hill. From the north and northeast, beyond a steep cliff and about $50 \mathrm{~m}$ below, lies the valley of the Rudawa River. On the western

\section{ब(ब्ब}



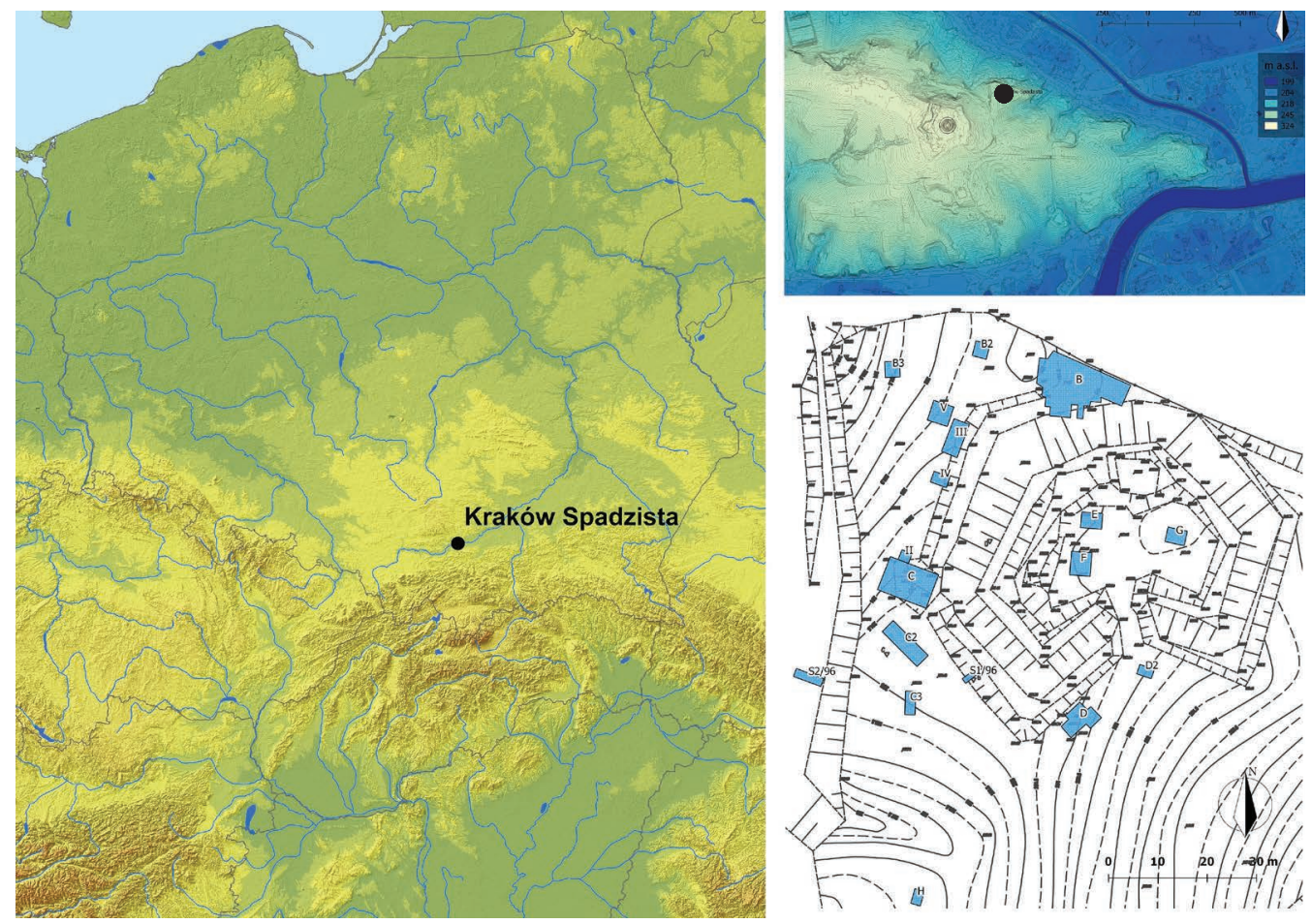

Fig. 1. Location of the Kraków Spadzista site. Layout by J. Wilczyński

side of Sikornik, a relatively mild (due to erosion) gorge about $150 \mathrm{~m}$ in length can be found, and in the east and partly in the southeast, runs a fairly deep gorge about $160 \mathrm{~m}$ in length, which begins in the valley of the Rudawa River and ends at a gentle neck of the headland from the south. The total surface area of the headland amounts to about 2 ha; whereas the surface of the plateau itself is about 1.5 ha (SoBCZYK 2015). Currently, the central part includes an Austrian earthen fort, construction of which partially damaged the Palaeolithic cultural layer (especially in the eastern part).

\section{History of investigations}

The site was discovered by accident in the late autumn of 1967 during a construction project that was later found to be illegal. Systematic research began in May 1968, with the cooperation of the palaeontologist Henryk Kubiak and archaeologist Janusz Krzysztof Kozłowski. To distinguish this site from the one at Spadzista Street (today, this part of the street is named 'Mieczysława Małeckiego Street'), discovered and investigated by J. K. Kozłowski in 1966, it was designated as 'Site B' (KozŁowsKI et al. 1974). After these fieldworks a series of excavations were conducted in different parts of the plateau, first in the area southwest of the main area with a mammoth bone accumulation, and in later years in the central and southern parts of the site known today. This fieldwork was conducted with many interruptions until 2017, and it allowed the range of occupation, its chronology and nature to be determined (WILCZYŃSKI et al. 2012, 2019). 
Trench G (area of $12 \mathrm{~m}^{2}$ ) was excavated during regular fieldwork carried out in 2017. It was one of five trenches established for determining the range of the Gravettian occupation (together with trenches B2 and B3 excavated in 2016 and trenches D2 and $\mathrm{H}$ investigated in 2017). It is so far the easternmost sector of the Kraków Spadzista site (Fig. 1). The fieldworks led at trench G revealed the remains of Neolithic occupation. These materials, along with remains linked with the $19^{\text {th }}$-century fort, are the only traces of non-Palaeolithic occupation at this site.

\section{Characteristics of the feature}

During regular archaeological excavations in the central part of trench $\mathrm{G}(4 \times 3 \mathrm{~m}$ in size), a single anthropogenic feature (designated as feature no. 1) was found. Its outline at the level of discovery was roughly circular, about 1.2-1.4 $\mathrm{m}$ in diameter (Fig. 2A). The feature was approx. $50 \mathrm{~cm}$ deep (120-150 cm from the ground surface) and was trough-shaped in cross-section (Fig. 2B). Two layers can be distinguished in its fill. The first one, without artefacts and light brown in colour, was located in the centre of the feature. The second, dark brown, contained archaeological and palaeobotanical materials (mainly charcoal and charred grains), which gave this layer a dark colour. In general, it lay on the bottom and along the side borders of the feature.

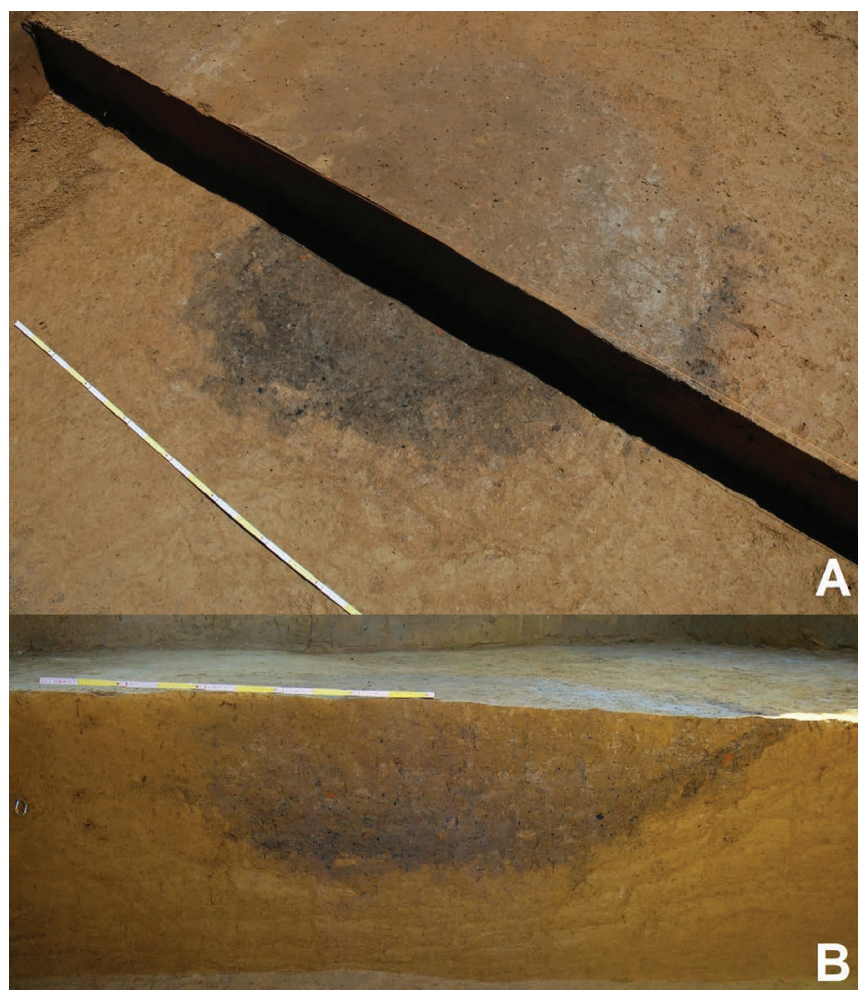

Fig. 2. Kraków Spadzista, trench G. Horizontal outline (A) and cross-section of the Neolithic feature (B). Photos by J. Wilczyński 


\section{MATERIALS AND METHODS}

All the types of archaeological materials found in feature no. 1 were studied. Pottery fragments were analysed taking into account their forms and technology, using standard manners of description and analysis of prehistoric pottery (e.g. GiBson, Woods 1997; Orton et al. 1993). The analysis of the lithic artefacts followed the method applied to lithic assemblages (BALCER 1983; INIZAN et al. 1999). The analysis of raw material used in the production of various artefacts is the first stage of the study. Raw material was described based on macroscopic observation which relies on identifying the colour and transparency of the source, description of the cortex, etc. Then, lithic materials were identified on the basis of own experience, lithic collection and publications (e.g. KaCZANOwSKa, KozŁOwsKi 1976). Lithic artefact size was recorded with three measurements: length, width and thickness. The whole inventory was divided into six different technological groups: cores, hammerstones, chips and uncharacteristic chunks, flakes, blades, and retouched tools. Blades and bladelets were not distinguished in this study, thus we use the term blade for all knapped artefacts having parallel edges and a length at least twice the width. Among the retouched tools, a few types were distinguished, such as endscrapers, truncated blades, and retouched blades.

The soil sample of volume of approx. 20 litres was water sieved (flotation) with the use of a $0.5 \mathrm{~mm}$ mesh sieve. It was collected at a depth of $120-170 \mathrm{~cm}$, from the lower layer of the feature. The heavy fraction was sieved with the use of a sieve with a mesh size of approx. $1.2 \mathrm{~mm}$. In addition, four samples from two parts (A and B) of feature no. 1 were hand-picked in places of visible concentration of charred plant materials, and they contained only wood charcoal remains. Taxonomical identification was based on seed and fruit morphology, including shape, size and character of the surface (for example: BIENIEK 2005; CAPPERS et al. 2006; JACOMET 2006; KULPA 1974; LityŃSKA-ZajĄC, WaSYLIKOWA 2005; NeEF et al. 2012). The reference collection of modern seeds and archaeobotanical remains stored in the W. Szafer Institute of Botany (IB PAS) was also used. The plant remains were identified under stereoscopic microscopes giving magnification from $6 \times$ to $63 \times$.

Charcoal fragments were taxonomically identified under a reflected light microscope (Zeiss Axio Lab. A1) with magnifications of 100-500×. Anatomical structure of wood was observed on freshly broken charcoal fragments. Botanical identifications were compared using anatomical atlases (e.g. SCHWEINGRUBER 1990) and a modern reference collection from the IB PAS. Woody taxa are mainly identified to genus level. If a taxon is determined to the species level it means that it represents the only species of a given genus in the present-day flora of the region (LITYŃSKA-ZAJĄC, WASYLIKOWA 2005). The quantification of charcoals was based on fragment counts (CHABAL 1997). Only fragments bigger than $1 \mathrm{~mm}$ in transverse section of wood were analysed. Micrographs were obtained thanks to scanning electron microscopy (SEM) from the Laboratory of Field Emission Scanning Electron Microscopy and Microanalysis at the Institute of Geological Sciences of the Jagiellonian University, Kraków, Poland. 
Radiocarbon age determinations were obtained at the Poznań Radiocarbon Laboratory. Two samples were selected from feature no. 1: 1) one grain of Triticum dicoccum, and 2) one charcoal fragment of Quercus sp.

Calibration procedures were performed using the OxCal package, ver. 4.3 (BRONK RAMSEY 2009).

\section{RESULTS}

\section{Pottery}

A total of 171 fragments of prehistoric pottery, weighing $746 \mathrm{~g}$, were discovered in feature 1 . The ceramic material is heavily damaged, which is mainly expressed by the high degree of fragmentation and the extensive surface erosion of about $80 \%$ of the sherds. The number of so-called characteristic fragments is very low. They consist of: i) two small rim fragments (Fig. 3: a, b ), ii) one rim fragment, probably with a small, partially preserved lug, placed at and just below the edge of the mouth (Fig. 3: f), iii) one banded handle, most probably of vertical orientation (Fig. 3d), iv) one small fragment of an undefined vessel with a conical knob (Fig. 3: c), v) one fragment of the base with a small fragment of the lower part of a vessel (Fig. 3: g), and - presumably - a small fragment of a spindle-whorl (Fig. 3: e).

The significant fragmentation of the pottery and the very low share of characteristic fragments make the technological analysis (with the technology reconstructed solely on the basis of macroscopic observations) the basic method of its examination, despite the poor state of preservation of the material also from this perspective.

Examining and correlating all the technological features that can be taken into account, we have concluded that this ceramic inventory, or in any case the vast majority of it, can be classified within a single technological entity, which can also be conventionally referred to as a technological group. This group is characterized by an average amount of temper in the form of broken sherds. In terms of size it is a non-homogeneous admixture, as it usually consists of fine (up to $1 \mathrm{~mm}$ ), medium, and coarse particles (over $2 \mathrm{~mm}$ ). Most often, sherds of this group have a three-layer cross-section, with outer, thin, light ("oxidizing") layers and an inner, dark ("reductive") core. In this case, the colour of the external and internal surfaces, in the cases we believe it can be reliably described, is light beige or light orange. The outer and inner surfaces are soft, often even "powdery" soft. No more than a dozen or so sherds with the described technological features, including the mentioned fragment of the base, are additionally distinguished by the presence of a mineral admixture, in the form of sand and gravel, along with the grog admixture.

Within the discussed technological group, we should perhaps distinguish a subtype in which vessel wall sections are uniform and grey-black, and the colour of both the external and internal surfaces is dark, i.e. dark brown or grey-black. This subtype would be distinguished by an admixture of broken sherds of smaller granulation, with 

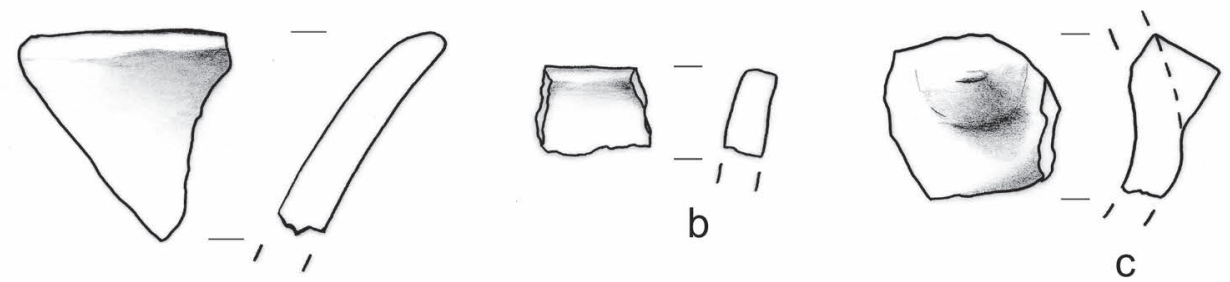

a

0 $1-5$ $5 \mathrm{~cm}$

C

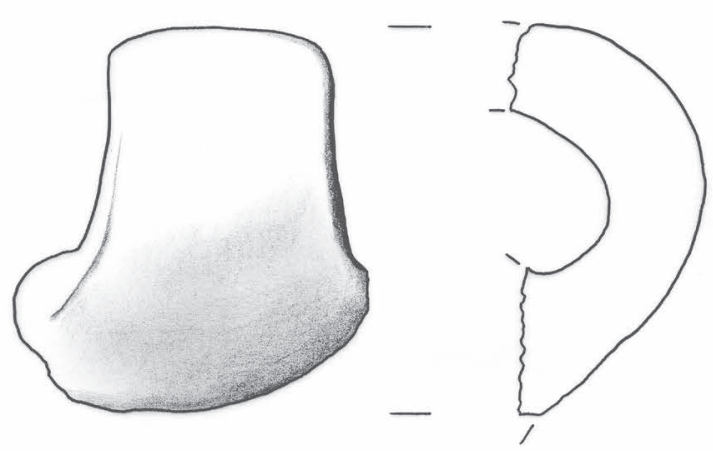

d

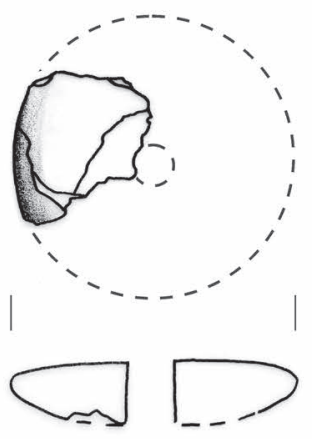

e
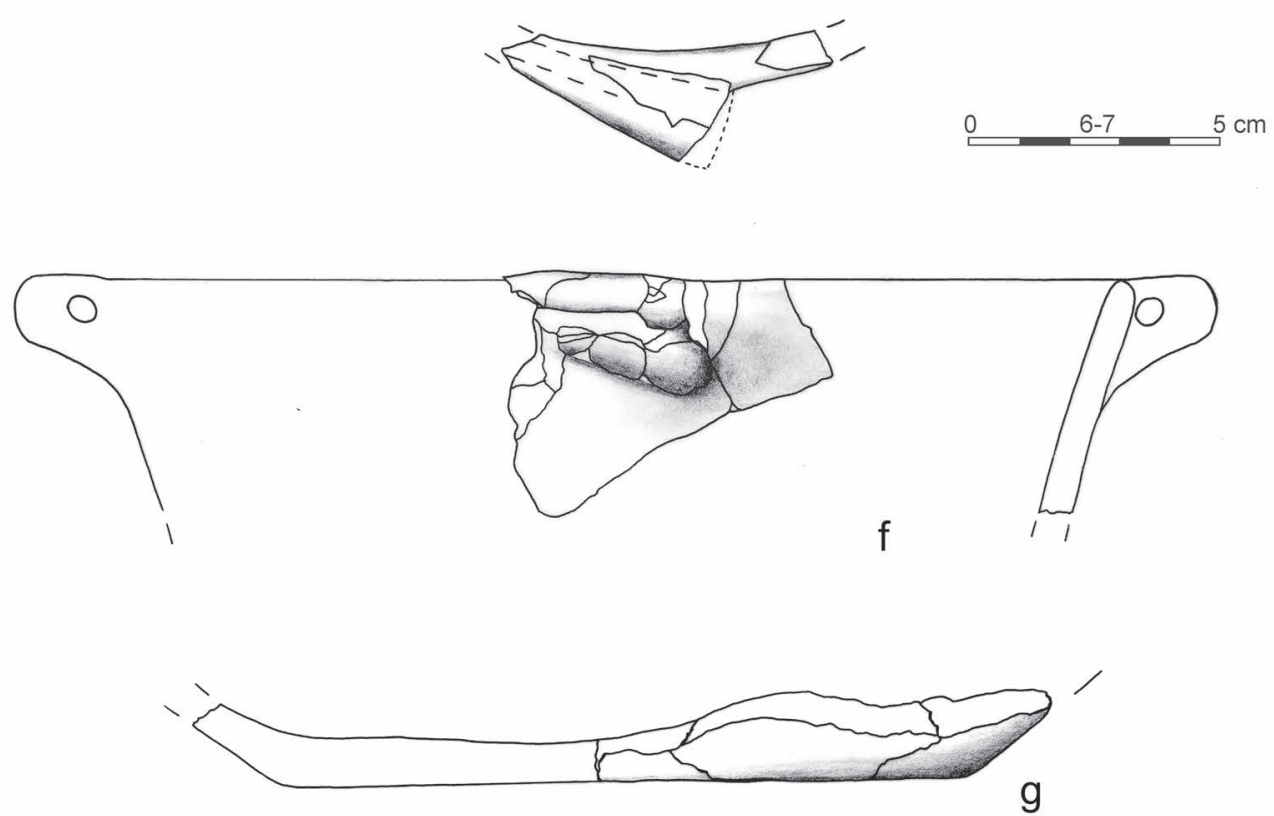

Fig. 3. Kraków Spadzista, trench G. Selected pottery recorded in the Neolithic feature. Drawn by A. Brzeska-Zastawna 
the coarse-grained fraction nearly absent. Perhaps there are also single particles of burnt flint or limestone. However, we are not entirely convinced whether such a subtype is a real prehistoric fact or the result of total erosion of the original external and internal layers of light shades.

The thickness of ceramic fragments with the above technology, if it can be properly assessed, varies between 6-7 and 10-11 $\mathrm{mm}$. On the other hand, a small group only of 19 fragments of thin-walled pottery having wall thickness of 4-5 mm was also recorded in the analysed material. Such sherds are also characterized by an admixture, although generally not very abundant, of fine and medium-grained grog. This admixture is occasionally supplemented with small particles of burnt flint or limestone and gravel grains. The cross-section is three-layered, with a dark core and outer, fairly dark, brown layers. The colour of the outer and inner surfaces can also be described as brown. The outer and inner surfaces are soft, but slightly harder compared to the aforementioned medium-walled pottery; there are no cases of "powdery" surfaces at all. All in all, it may be justified to distinguish a second technological group, limited to the mentioned 19 thin-walled pieces, which seem slightly better fired and more carefully finished.

The technological status of the ceramic inventory from the feature in question, in the form of both suggested groups, corresponds to a very large extent to the typical technology of middle Neolithic pottery. This means that in western Lesser Poland we could look for links with the units of the Lengyel-Polgár complex (rather from its middle or late developmental stage), with the Funnel Beaker culture, or with the Baden culture. Since the very small number of characteristic fragments makes it impossible to reliably refer our material to any of the above-mentioned entities, we will go a little ahead of the course of our argument and refer to the two radiocarbon dates obtained from the feature (see below). These dates are internally consistent and indicate - most probably - the end of the first half of the $4^{\text {th }}$ millennium BC. With the current state of knowledge, it seems that such a chronology can still be attributed to the most recent Lengyel-Polgár unit in western Lesser Poland, i.e. the Wyciąże-Złotniki group, or to be more precise, to its latest stage (NowAK 2017: 262, 263). However, this is undoubtedly a highly debatable issue and it is not likely that all researchers would agree with this opinion. In other words, it is possible that the disappearance of the Wyciąże-Złotniki group had already taken place ca. 3700 BC (NowaK 2014). The other possible candidate is the Funnel Beaker culture, as the presented absolute chronology is too early for the Baden phenomena, either in pure or in syncretic form. The Funnel Beaker culture appears in western Lesser Poland no later than approx. $3750 / 3700 \mathrm{BC}$ in a conservative scenario recently proposed by one of the authors (NOWAK 2017: 263, 264; 2019). However, according to other researchers, it appears earlier, somewhere between 3950 and 3800 BC (KruK, MilisausKas 2018; KRUK et al. 2016; KRUK et al. 2018; MilisausKas et al. 2016).

One should also add that in the fill of the feature, only in the dark layer, a relatively large amount of daub was found: several hundred pieces with a total weight of $1165 \mathrm{~g}$. Unfortunately, it was not possible to notice any constructional imprints on their surfaces. In several cases we are not sure whether we are dealing with daub, or with a very strongly burnt loess. 


\section{Lithic materials}

During exploration of the Neolithic feature a scant stone assemblage was discovered. The entire chipped stone inventory was made on local Jurassic flint, brown and grey-brown in colour (33 specimens, including a flint hammerstone, blanks, and retouched tools). This kind of raw material occurs in great abundance near Kraków and the southern rim of the Kraków-Częstochowa Jura. The nearest outcrops are located directly at the site, and lumps of this flint can be found even in the limestone cliff bounding the site from the north. Moreover, a single flake made of unidentified raw material (weathered slate?) and a grindstone made on a sandstone slab were described as well. The most likely place for extraction of these raw materials was the Vistula riverbed, filled by alluvial deposits.

Among the 33 lithic artefacts the most numerous groups are those of flakes, and of chunks and chips (Tab. 1). But apart from these artefacts, a set of five retouched tools was discovered as well.

A single flake core with changed orientation represents the final stage of reduction. It was made of grey-brown Jurassic flint, and has the dimensions $67 \times 50 \times 38 \mathrm{~mm}$.

A flint hammerstone made from Jurassic flint is slightly bigger than the core $(79 \times 78 \times 24 \mathrm{~mm})$. This is a circular specimen, with numerous damages resulting from its use (e.g. flint chipping). Processing of flint on the site is also evidenced by refitting of the hammerstone with a single flake.

Flakes (13 specimens) include seven whole specimens, a single mesial fragment, and six distal fragments. Among them small flakes prevail, with only two pieces longer than $5 \mathrm{~cm}$. Most of them are covered by cortical or thermal surfaces. Five specimens have almost entirely natural surfaces. The dorsal pattern of the flakes is diversified: the observed scars can be unipolar, bipolar or transversal.

Blades are represented by three fragments and a single whole specimen $(77 \times 28 \times 12 \mathrm{~mm})$. These are rather massive and not always regular blades. The butts

Table 1. Kraków Spadzista, trench G. Lithic artefacts discovered in feature no. 1

\begin{tabular}{|c|c|c|c|}
\hline \multicolumn{2}{|l|}{ Finds } & $\mathrm{N}$ & $\%$ \\
\hline \multicolumn{2}{|l|}{ Core } & 1 & 3 \\
\hline \multicolumn{2}{|l|}{ Flint hammerstone } & 1 & 3 \\
\hline \multicolumn{2}{|l|}{ Chunks and chips } & 8 & 24,2 \\
\hline \multicolumn{2}{|l|}{ Flakes } & 13 & 39,5 \\
\hline \multicolumn{2}{|l|}{ Blades } & 4 & 12,1 \\
\hline \multicolumn{2}{|l|}{ Retouched tools: } & \multirow{5}{*}{5} & \multirow{5}{*}{15,2} \\
\hline Double endscraper & 1 & & \\
\hline Truncated blade & 1 & & \\
\hline Retouched blades & 2 & & \\
\hline Retouched flake & 1 & & \\
\hline \multicolumn{2}{|l|}{ Grindstone } & 1 & 3 \\
\hline \multicolumn{2}{|l|}{ Total } & 33 & 100 \\
\hline
\end{tabular}



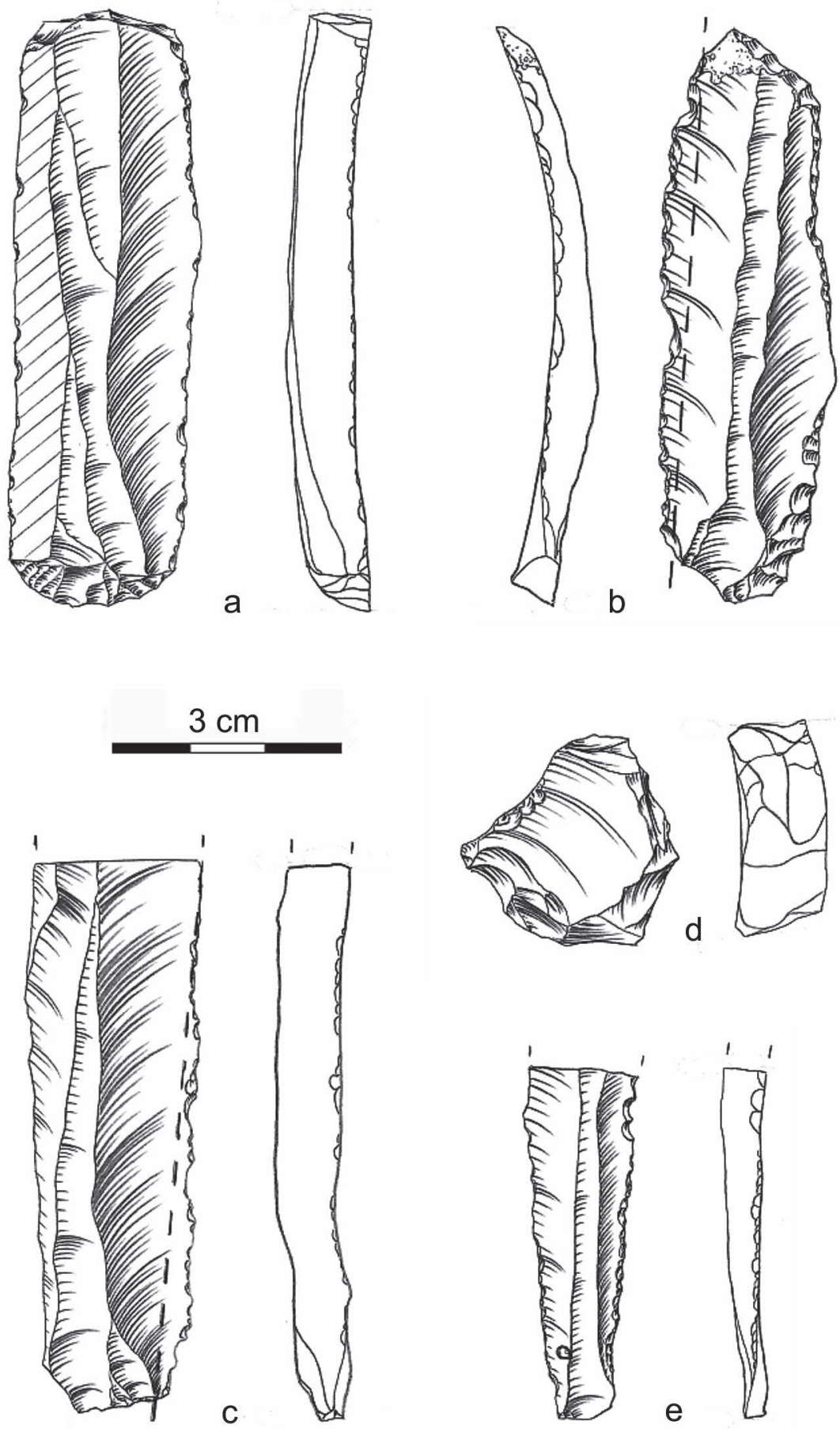

Fig. 4. Kraków Spadzista, trench G. Lithic tools recorded in the Neolithic feature. Drawn by J. Wilczyński 
of these specimens were created by several blows, and lips are evident on the ventral sides. This suggest the soft-hammer technique was used for their production.

Among the retouched tools we can discern a single double endscraper (Fig. 4: a) made on a regular, massive blade $(76 \times 23 \times 8 \mathrm{~mm})$, a wholly preserved truncated blade (Fig. 4: b) with visible sickle gloss $(72 \times 22 \times 6 \mathrm{~mm})$, and two proximal parts of retouched blades $(70 \times 23 \times 7$ and $45 \times 14 \times 4 \mathrm{~mm}$ diameter) (Fig. 4: c, e), one of them also with noticeable sickle gloss (Fig. 4: c). Additionally, one atypical retouched flake can be mentioned (Fig. 4: d).

A grindstone made of coarse-grained sandstone is preserved as a thick fragment $(68 \times 62 \times 43 \mathrm{~mm})$, with a single flat surface bearing traces of polishing.

\section{Archaeobotanical remains}

The plant material was dominated by uncharred seeds of Chenopodium album (Fig. 5), which in that dry, open-air site must be interpreted as a modern contamination, as some remains of the soil seed bank (CAVERs, Benoit 1989; Mueller-BienieK et al. 2018). The rest of the remains were preserved in charred form. In Table 2 the minimal number of items is given. Most of the cereals and large grains of grasses were not preserved as whole specimens.

In feature no. 1 remains of cultivated and wild plants were found. Grains of einkorn (Triticum monococcum) and emmer (T. dicoccum) were found in equal proportions. Most of the crop grains were very badly preserved and their identification to the genus level was not possible. Single glume bases were also noted.

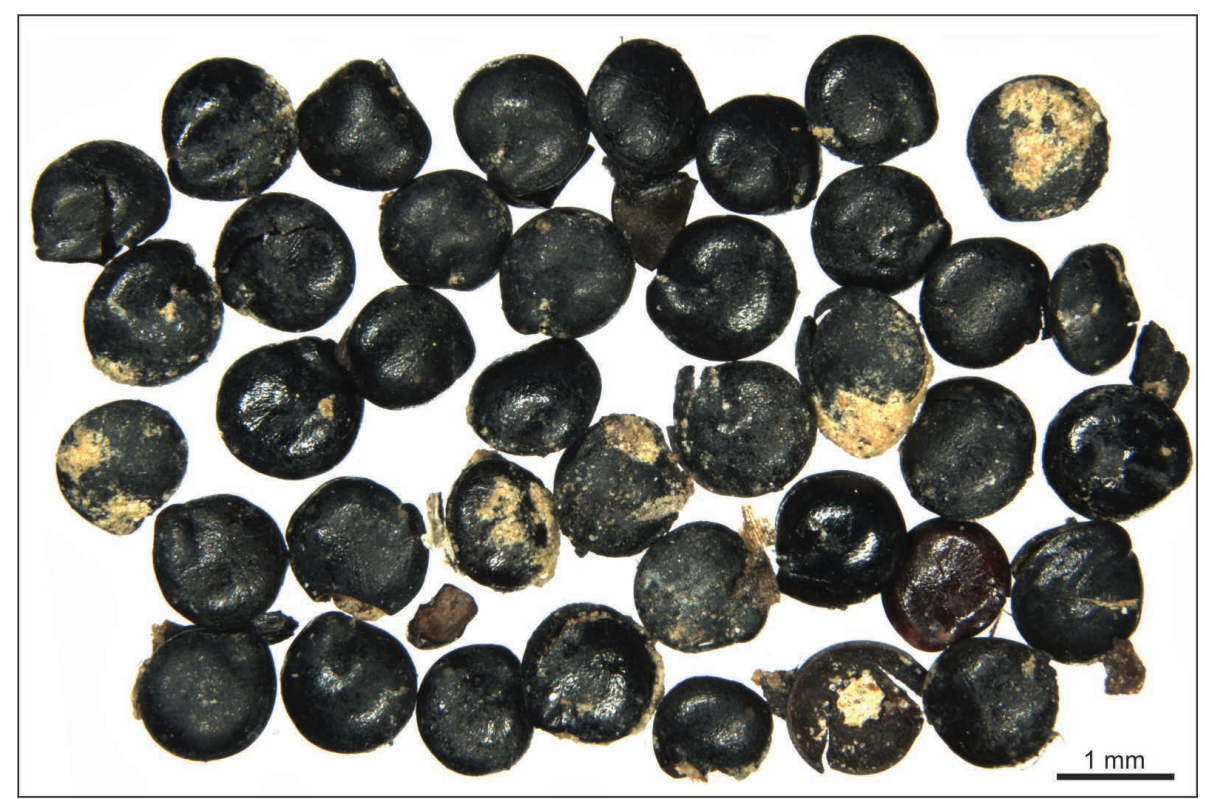

Fig. 5. Kraków Spadzista, trench G. Uncharred seeds of fat-hen (Chenopodium album type), modern contamination of archaeological sample. Photo by K. Stachowicz 
Table 2. Kraków Spadzista, trench G. Plant macro-remains from feature no. 1. Plant names after (MireK et al. 2002)

\begin{tabular}{|l|l|c|}
\hline Taxa & Type of remain & $\begin{array}{c}\text { Minimal number } \\
\text { of specimens }\end{array}$ \\
\hline Cultivated plants & \multicolumn{2}{|l|}{} \\
\hline Triticum dicoccon (=T. dicoccum) & grain & 4 \\
\hline Triticum dicoccon & glume base & 1 \\
\hline Triticum monococcum & grain & 4 \\
\hline Triticum sp. & glume base & 1 \\
\hline Cerealia indet. & grain & 6 \\
\hline Cerealia indet./Poaceae indet. & grain & 7 \\
\hline Cerealia indet./Poaceae indet. & culm/rhizome & 3 \\
\hline cf. Linum usitatissimum & seed & 1 \\
\hline Wild plants & \multicolumn{2}{|l|}{} \\
\hline Bromus racemosus/arvensis & grain & 12 \\
\hline Galium spurium & fruit & 2 \\
\hline Poa annua & grain & 1 \\
\hline Phleum sp./Poa sp. & grain & 1 \\
\hline Polygonum lapathifolium & fruit & 1 \\
\hline Fallopia convolvulus & fruit & 1 \\
\hline Coronilla varia & seed & 1 \\
\hline indet. & seed/fruit & 1 \\
\hline Cenococcum & sclerotia & 47 \\
\hline Uncharred - modern contamination & \multicolumn{2}{|l|}{} \\
\hline Chenopodium t. album & seed & 43 \\
\hline
\end{tabular}

The only find possibly identifiable as flax (cf. Linum usitatissimum) is uncertain because of the severe damage to the specimen. The shape of its one side and the specific type of its damage due to high temperature make it very similar to a well-identified group of flax seeds from the Mozgawa site (Mueller-BienieK, KAPCiA, unpublished).

In the group of cultivated plants stem fragments of Cerealia or Poaceae are also listed (Fig. 6: g). On one of them some remains of roots are still preserved, which indicates that we found a part of a rhizome.

Among the plants which are now known as wild plants, brome grass grains (Bromus racemosus/arvensis) prevailed (Fig. 6: a). We cannot exclude other species were present as well, but all fragments in which the lower part was well-preserved and the shape was recognizable indicated B. racemosus type (GLUZA 1977).

Other taxa were represented by single items of plants growing in open areas, known as weeds (Galium spurium, Fig. 6: f and Polygonum lapathifolium, Fig. 6: c, Fallopia convolvulus, Fig. 6: b) and grassland plants (Coronilla varia, Fig. 6: e, Poa annua, Fig. 6: d and Phleum sp./Poa sp.) (KaPCia, Mueller-BienieK 2019).

The charcoal fragments were badly preserved and plant tissues were filled with small sediments (Fig. 7). Among the wood charcoal fragments, 100 fragments were analysed from the flotation sample, and this number was sufficient for documenting 


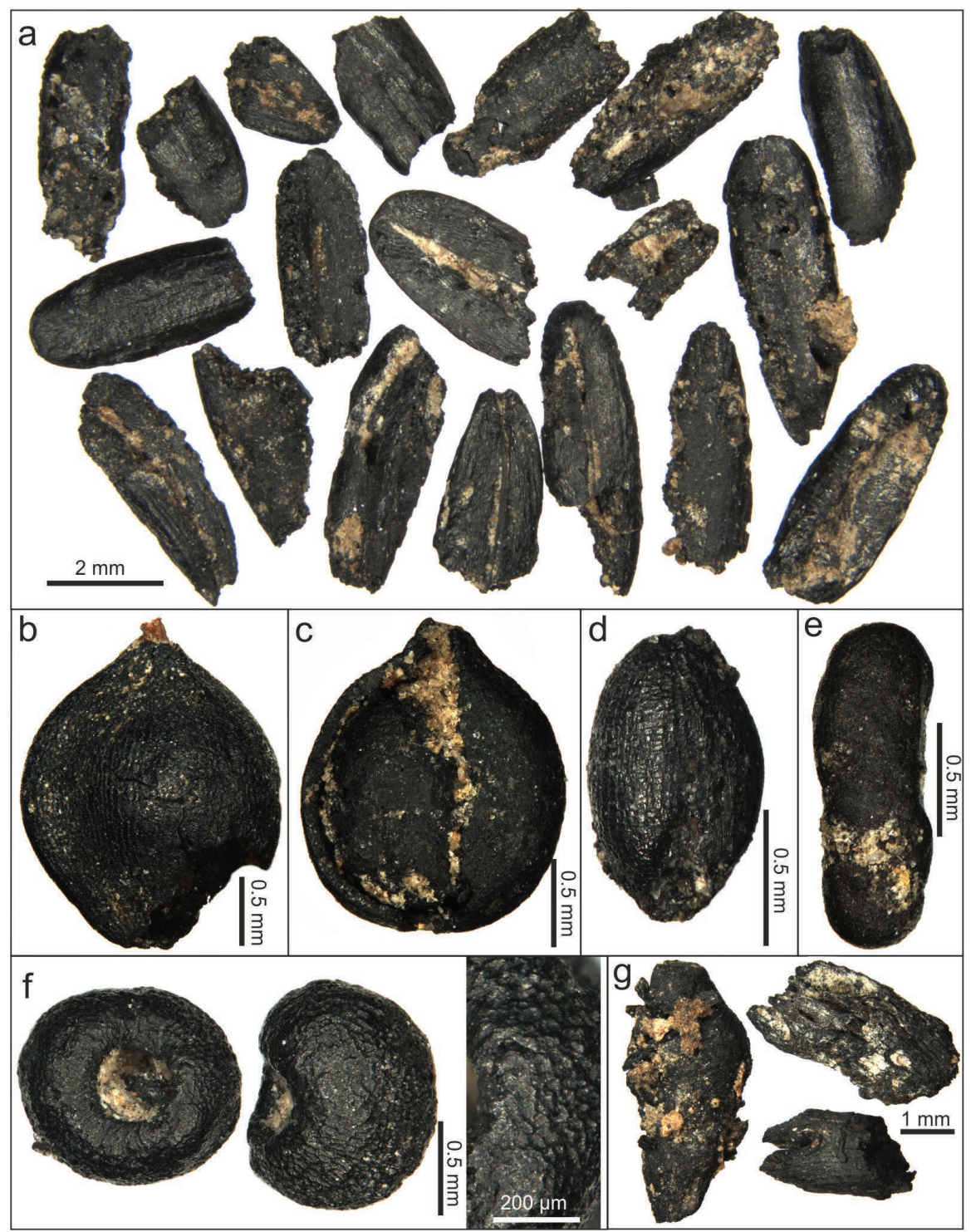

Fig. 6. Kraków Spadzista, trench G. Macroscopic plant remains from feature no. 1: Bromus sp. (a), Fallopia convolvulus (b), Polygonum lapathifolium (c), Poa annua (d), Coronilla varia (e), Galium spurium (f), Cerealia indet./Poaceae indet - fragments of stem/rhizome (g). Photos by K. Stachowicz and M. Kapcia

the taxonomic diversity based on a taxonomic curve applied to this assemblage (all taxa appeared in the first 12 analysed fragments). Altogether five taxa were identified, including species (ash Fraxinus excelsior), genus (alder Alnus sp., birch Betula sp., oak Quercus sp.) and broad-leaved tree or shrub (Tab. 3). F. excelsior is a dominant taxon since its fragments constituted 70\% (Fig. 7: a, b) of the entire charcoal assemblage, followed by Quercus sp., Betula sp. and Alnus sp. (Fig. 7: c-f). The same 

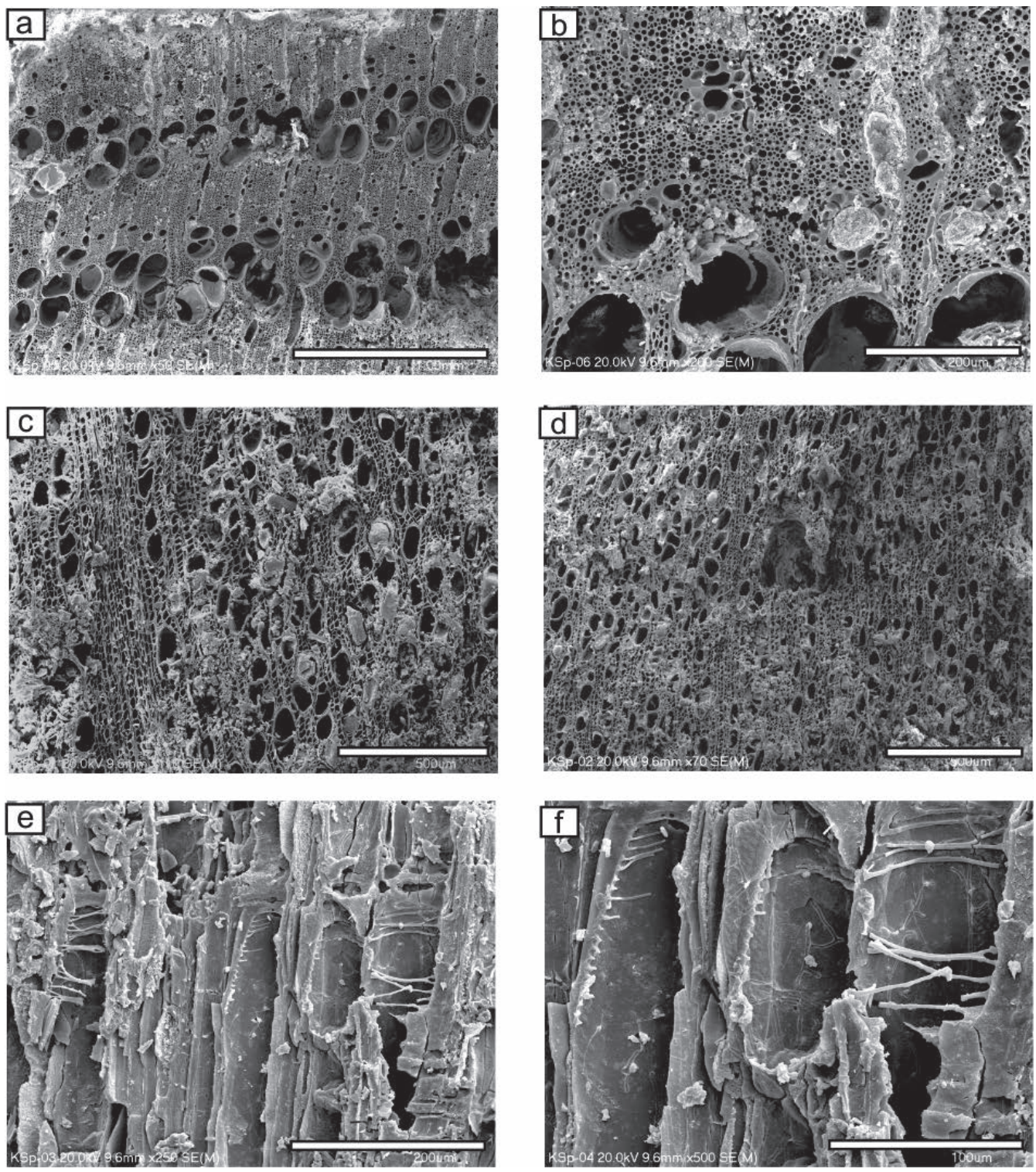

Fig. 7. Kraków Spadzista, trench G. Selected charcoal fragments from feature no. 1: Fraxinus excelsior in transverse section (a-b), Alnus sp. in transverse section (c-d) and in longitudinal radial section (e-f). Scale bars: $1.00 \mathrm{~mm}$ (a), $200 \mu \mathrm{m}$ (b, e), $500 \mu \mathrm{m}$ (c-d), $100 \mu \mathrm{m}$ (f). Micrographs by M. Moskal-del Hoyo

proportions of taxa were observed in four hand-picked samples, where remains of F. excelsior clearly predominated, while Alnus sp. was less frequent. Also, remains of bark were relatively abundant, as in floated sample bark remains count for 45 fragments (Tab. 3). In addition, in floated sample it was impossible to assess based on ring curvature if the charcoals came from wood of trunks or from branchwood (MARGUERIE, HunOT 2007). However, in hand-picked samples a few branch fragments belonging to 
Table 3. Kraków Spadzista, trench G. Wood charcoal remains from feature no. 1

\begin{tabular}{|c|c|c|c|c|c|c|}
\hline & $\begin{array}{l}\text { Flotation } \\
\text { sample }\end{array}$ & \multicolumn{4}{|c|}{ Hand-picked samples } & \multirow[b]{2}{*}{ Total } \\
\hline & $120-170 \mathrm{~cm}$ & $\begin{array}{c}\text { Part A, } \\
120-150 \mathrm{~cm}\end{array}$ & $\begin{array}{c}\text { Part A, } \\
150-170 \mathrm{~cm}\end{array}$ & $\begin{array}{c}\text { Part B, } \\
120-150 \mathrm{~cm}\end{array}$ & $\begin{array}{c}\text { Part B, } \\
150-170 \mathrm{~cm}\end{array}$ & \\
\hline Fraxinus excelsior & 70 & 23 & 18 & 25 & 13 & 149 \\
\hline Alnus sp. & 7 & 3 & & & & 10 \\
\hline Betula sp. & 9 & 6 & & 3 & 1 & 19 \\
\hline Quercus sp. & 12 & 8 & 2 & 2 & & 24 \\
\hline Broad-leaved & 2 & & & & & 2 \\
\hline $\begin{array}{l}\text { Total no. } \\
\text { of fragments }\end{array}$ & 100 & 40 & 20 & 30 & 14 & 204 \\
\hline Bark & 45 & 3 & & 3 & & \\
\hline Fungi & 8 & 1 & 1 & 3 & & \\
\hline Branch wood & & 3 & 3 & 4 & & \\
\hline
\end{tabular}

F. excelsior and Betula sp. were observed. Three fragments of Quercus sp. represented twigs (Tab. 3). A few fragments showed the presence of fungi (Fig. 7: f) and insects (Fig. 7: d), probably meaning that some part of the wood used came from decayed deadwood (MosKal-Del Hoyo et al. 2010).

\section{Absolute dating}

Two radiocarbon dates were obtained from the object in question, (Fig. 8), both from the "bottom", dark layer, in which practically all the archaeological material oc-

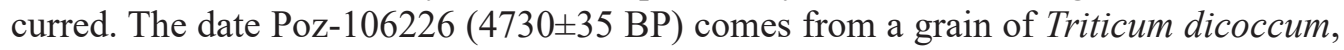
i.e., a short-lived material. Unfortunately, it falls within a range of the calibration curve which is characterized by a fairly wide plateau. As a result, after calibration, we obtain in the 2sigma version a quite broad, not continuous, time interval of 3640-3370 BC. The second date was obtained from charcoal identified as Quercus sp. (a twig found in a hand-picked sample, part A, $120-150 \mathrm{~cm}$ ), but fortunately it is most likely a twig, thus it is quite possible that the result Poz-107135 (4810 35 BP) was not too much influenced by the old wood effect. After calibration we obtained a much narrower range of 3660-3520 BC. Generally speaking, it can be stated that both dates fit together, or in any case they are dates of the same order. As could be expected in theory, the uncalibrated date from the emmer grain is slightly younger. Nevertheless, the calibration intervals overlap to a considerable extent, as confirmed by the relevant statistical procedure (Fig. 8: c).

In this situation, two alternative scenarios should be considered as the most likely. The first one assumes that the shared part of calibration intervals of both dates, which should be set for a period of about 3640-3520 (Fig. 8: c), determines the timeframe within which the feature was excavated and probably filled. It may even be suggested that this took place around $3570 \mathrm{BC}$, but such a suggestion is only the result of specific statistical calculations; we should not get too attached to it. The second scenario, 

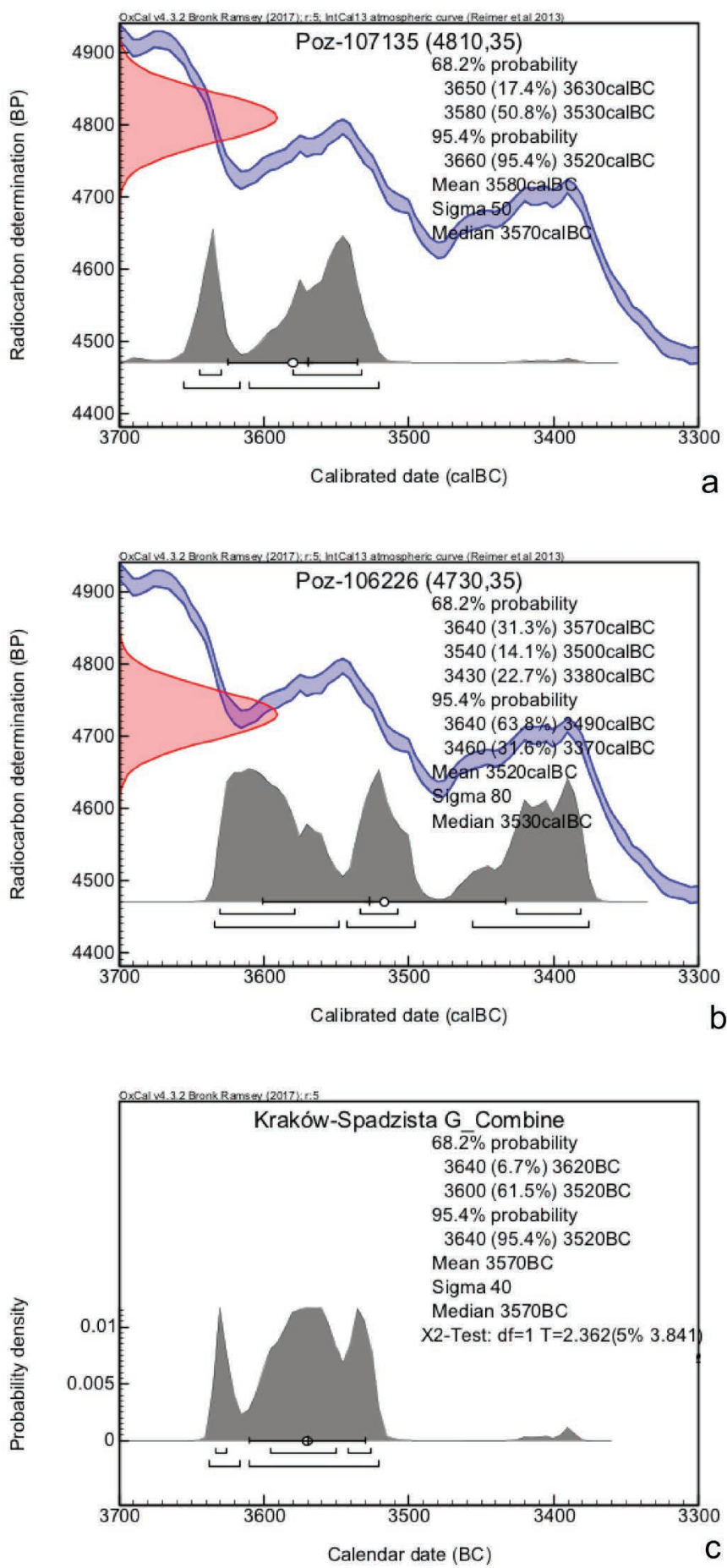

Fig. 8. Kraków Spadzista, trench G. Calibrations of the 14C dates obtained in the Neolithic feature (a, b) and their statistically confirmed common part (c). Layout by M. Nowak 
on the other hand, assumes that the age of the oak twig is still older than the age of the wheat grain, and thus the object would have been dug up and used in some part of the period later than $3520 \mathrm{BC}$, lasting up to about $3370 \mathrm{BC}$. Perhaps we should especially consider the range 3460-3370 BC (Fig. 8: b). However, we believe that the second scenario is slightly less probable, since - as already stated - the old wood effect may not be significant at all in the case of a thin twig. On the other hand, it cannot be ruled out that a branch that was naturally broken off and/or charred in the $37^{\text {th }}$ or $36^{\text {th }}$ century $\mathrm{BC}$ accidentally entered the fill of the feature during its digging and use in the $35^{\text {th }}$ or early $34^{\text {th }}$ century BC.

\section{DISCUSSION}

In terms of technology, the pottery from the feature discovered in trench $\mathrm{G}$ is consistent with our knowledge about pottery of both the Wyciąże-Złotniki group and the Funnel Beaker culture; single sherds with mineral temper do not change this conclusion (Grabowska, Zastawny 2011: 127-128; KluziK 2010; KruK, MilisausKas 2018: 52-54; NOWAK 2004: 126, 2010, 2014, 2015: 16-20; NowAK et al. 2007; ZASTAWNY 2014: 23; ZASTAWNY et al. 2011: 251-253). The small number of characteristic fragments, which is probably due to the high degree of fragmentation and destruction of the inventory, makes it virtually impossible to distinguish between these two units. Although elements such as a mouth with a small lug, a banded handle, or a cone-shaped knob are formally typical of the Wyciąże-Złotniki group (KozŁowsKi 2006; NowAK 2014), their presence may also be easily demonstrated in many "beaker" inventories in western Lesser Poland (e.g. KruK, MilisausKas 2018: figs 12: 5, 18; 16: 13; 44: 18; 47: 6; 55: 5; 77: 13; 83: 3; NoWAK 2015: plates XII: 2; XIV: 2; ZASTAWNY et al. 2011: fig. 13: 14; plate XI: d). In addition, the aforementioned lug is different from the most typical small lugs of the Wyciąże-Złotniki group.

Since the chronology of the latter unit after ca. 3700 BC is debatable, we think that a connection between feature no. 1 at the Kraków Spadzista site and the Funnel Beaker culture is more probable. Obviously, if one considers the alternative scenario of absolute chronology (see below), which postulates dating the feature within the 35 th and early 34th centuries BC, then its relationship with the Funnel Beaker culture becomes much more likely.

The flint inventory does not contradict the hypothesis about the relationship of the creators of the feature with either the Wyciąże-Złotniki group or the Funnel Beaker culture. Particularly the size and type of retouched tools can be considered in the middle Neolithic context (BALCER 1983). By the way, the silica gloss recorded on the blade tools seems to be slightly more typical of the Funnel Beaker culture. Irrespective of this issue, it should be emphasised that the presence of the core, the flint hammerstone, and the numerous flakes, chips and chunks confirm chipping flint nodules directly on the site. Moreover, the occurrence in this assemblage of numerous cortical flakes shows that whole lumps of raw material covered with natural surface were transported 
to the site. Their size and technological features indicate that flint nodules processed at the site were small and not of the highest quality. This production was focused on everyday needs. The majority of the flakes come from initial and final stages of nodule processing, while regular, non-cortical blades are almost missing. The structure of the lithic inventory: the presence of numerous flakes and a few blade fragments, can be result of the obtained blanks being removed from the site. Moreover, some of the most regular retouched tools and blanks used for their production were probably brought from outside the site, most likely from a specialized flint workshop (e.g. endscraper and blade fragment Fig. 4: a, c).

Although plant macro-remains found at the Kraków Spadzista site are not abundant, representing rather scattered remains left by diverse activities, its value for the research on the Funnel Beaker culture is significant. The composition of cultivated plants, namely einkorn and emmer wheats, is quite common in Neolithic sites of southern Poland (LityŃSKA-ZająC 2007; LityŃSKA-ZająC et al. 2017), but in the Kraków Spadzista site the relatively high importance of einkorn is rather exceptional because grains of it were found in equal proportion to emmer grains. Einkorn is usually noted only as an admixture in emmer yields (KRUK et al. 2016). In Northern Poland, namely in the Kuyavia region, emmer or the 'new' glume wheat type dominated in the Neolithic materials as well (BIENIEK 2007, 2002; MUELLER-BIENIEK et al. 2016). The dominance of einkorn remains was noted in single Neolithic sites from Kuyavia: Ludwinowo 7 (MuelLer-BIENIEK et al. 2019) and Osłonki 2 (MuelLer-BIENIEK 2016). The presence of einkorn and emmer wheats is typical for the Funnel Beaker culture, but the relatively high share of einkorn is atypical for FBC sites in southern Poland (Kotynia 2016; Kruk et al. 2016; Moskal-Del Hoyo et al. 2017, 2018; NowaK 2009). Einkorn is more resistant than other wheats to unfavourable climatic conditions, like frost or too high precipitation in summer (GLUZA 1994; KRUK et al. 2016). It can survive in worse ecological circumstances than most other cultivated plants.

Among other cultivated plants, flax probably appeared. This plant, part of the Near Eastern crop 'package' (ZoHARY et al. 2012), was known in Poland since the beginning of the Neolithic but was very scarce (LityŃSKa-ZająC et al. 2017; MueLLER-BiENiEK et al. 2016, 2019).

Among wild plants, remains of brome grass outnumbered all other charred remains. This plant, mostly the species $B$. racemosus and B. arvensis, was commonly found in the Neolithic archaeobotanical assemblages, especially in the Funnel Beaker storages, sometimes outnumbering remains of wheats (GLUZA 1984; KAPCIA, MUELLER-BIENIEK 2018; KRUK et al. 2016). In Neolithic and Bronze Age sites it is usually interpreted as a useful edible plant (BeHre 2008; BIENIEK 2002; GluZA 1984). Like einkorn, brome grass can survive in worse ecological circumstances than other cultivated plants.

The fragments of stems, including underground parts of rhizomes, and the relatively small number of wheat chaff remains suggest that crops were harvested by plucking the whole plant. Stem fragments are rarely noted in Polish archaeological sites, while chaff remains of hulled wheats can be very numerous (LiTYŃSKA-ZAJĄC, WASYLIKOWA 2005), reflecting dehusking practices (KRUK et al. 2016). The relatively high representation of 
plants growing in grasslands (Coronilla varia, and small seeded grasses) suggests that some remains of fodder (possibly hay) are preserved in the material. On the other hand, a typical weed of winter crops and flax (Galium spurium) (LiTYŃSKA-ZAJĄC 2005) was also noted, represented by two charred remains. This may be an argument in favour of the use of flax by the settlers, a plant represented by one severely deformed specimen.

It is likely that charred wood remains originated from firewood, due to the presence of dispersed fragments of at least four different taxa of trees and shrubs, their bad state of preservation, and the presence of decayed wood. The taxonomic list may suggest that the wood was gathered from local forests, mostly deciduous forests with ash and oak. The dominance of Fraxinus excelsior indicates an occurrence of areas with greater soil humidity, although this species can tolerate very wide hydrological, soil and light conditions, and it grows mostly in warm temperate climates among mesotrophic and eutrophic forest communities (SENETA, DolatowsKi 2004; TовOLSKI, NALEPKA 2004). This can be linked with the proximity of the site to the Rudawa valley. According to the natural potential vegetation (MATUSZKIEWICZ 2008), oak-hornbeam forests (Tilio-Carpinetum) would have developed in the area, with oak forests (Luzulo luzuloidis-Quercetum) and beech forests (Dentario glandulosae-Fagetum) covering the area of the headland, as well as patches of xerothermic grasslands (Festucetalia valesiacae). These plant communities are in accordance with a map of natural vegetation of Kraków prepared more than 50 years ago (Kornaś, Medwecka-Kornaś 1967). Taking into account that important constituents of present-day woodlands, such as hornbeam Carpinus betulus and beech Fagus sylvatica, were probably not growing in the fourth millennium BC in this region (RALSKA-JASIEWICZOWA et al. 2004), forests of that time were different than present-day vegetation. Usually, in other plant assemblages from the Neolithic archaeological sites of southern Poland, oak is a predominant taxon (i.e. LitYŃSKA-ZAJĄC 1997; MosKal-DEL HoYo et al. 2017, 2018), but it is commonly followed by ash in areas located close to the river banks, such as Kraków-Pleszów site 17 located in the close vicinity of the Vistula River (GluzA et al. 1988) and in general was the second most frequent taxon in all Neolithic assemblages from the Kraków-Nowa Huta region (WaSYLIKOWA et al. 1992). The Neolithic charcoal assemblage from the Kraków Spadzista site is not very representative for a reconstruction of past woodland vegetation because it is based only on materials found in one archaeological feature, with a possible problem of over-representation of some taxa. However, it is a documentation of diverse wood used by people as firewood, which was gathered locally in deciduous forests.

\section{CONCLUSION}

The feature described in this paper is the first signal of activity of Neolithic populations within this widely known classical Palaeolithic site. Although the feature is (so far) an isolated find, it indicates a longer stay of a Neolithic group in a place where the activity of Gravettian mammoth hunters had been concentrated over twenty thousand 
years earlier. This is indicated, for example, by the fact that the initial stage of blanks knapping has been identified in the flint material, and by the considerable amount of daub recorded in the feature. The latter most probably found its way to the fill from some architectural structure erected nearby. Remains of the "standard" Neolithic plant economy also corroborate this supposition.

ACKNOWLeDGements. The archaeobotanical work was supported by the W. Szafer Institute of Botany (Polish Academy of Sciences, Kraków) through its statutory funds.

\section{REFERENCES}

BALCER B., 1983. Wytwórczość narzędzi krzemiennych w neolicie ziem Polski. Ossolineum. WrocławWarszawa-Kraków-Gdańsk-Łódź.

BeHRE K.-E., 2008. Collected seeds and fruits from herbs as prehistoric food. Vegetation History and Archaeobotany 17: 65-73. DOI: 10.1007/s00334-007-0106-x

BienieK A., 2002. Archaeobotanical analysis of some early Neolithic settlements in the Kujawy region, central Poland, with potential plant gathering activities emphasised. Vegetation History and Archaeobotany 11: 33-40. DOI: 10.1007/s003340200004

BiENIEK A., 2005. „Nowy” typ pszenicy oplewionej w materiałach archeobotanicznych. In: Wasylikowa K., Lityńska-Zając M., Bieniek A. (Eds), Roślinne ślady człowieka, Botanical Guidebooks. Kraków: 265-280.

BiENiEK A., 2007. Neolithic plant husbandry in the Kujawy region of central Poland. In: Colledge S., Conolly J. (Eds.), The Origins and Spread of Domestic Plants in Southwest Asia and Europe. Routledge: $327-342$.

BRONK RAMSEY Ch., 2009. Bayesian analysis of radiocarbon dates. Radiocarbon 51: 337-360.

CAPpers R.T.J., Bekker R.M., JANS J.E.A., 2006. Digital Seed Atlas of the Netherlands. Barkhuis. Groningen.

Cavers P.B., Benoit D.L., 1989. Seed Banks in Arable Land. In: Leck M.A., Parker V.T., Simpson R.L. (Eds.), Ecology of Soil Seed Banks. Academic Press: 309-328. DOI: 10.1016/B978-0-12-440405$2.50019-1$

Chabal L., 1997. Forêts et sociétés en Languedoc (Néolithique final, Antiquité tardive) L'anthracologie, méthode et paléoécologie. Éditions de la Maison des sciences de l'homme. Paris.

Gibson A., Woods A., 1997. Prehistoric Pottery for the Archaeologist. Leicester University Press, London - Washington.

GluZA I., 1977. Remains of the genus Bromus from a Neolithic site in Kraków. Acta Palaeobotanica 18: $17-34$.

GLuZA I., 1984. Neolithic cereals and weeds from the locality of the Lengyel Culture at Nowa Huta-Mogiła near Cracow. Acta Palaeobotanica 23: 12-184.

GLuZA I., 1994. Wstępne wyniki badań odcisków roślinnych ze stanowisk kultury ceramiki wstęgowej rytej w Gniechowicach i Starym Zamku, woj. wrocławskie. In: Warsztaty Archeobotaniczne Igołomia, Polish Botanical Studies, Guidebook Series. Kraków: 55-69.

GluZa I., TomczyŃska Z., Wasylikowa K., 1988. Uwagi o użytkowaniu drewna w neolicie na podstawie analizy węgli drzewnych ze stanowisk archeologicznych w Krakowie-Nowej Hucie. Materiały Archeologiczne Nowej Huty 12: 7-26. 
Grabowska B., Zastawny A., 2011. Materiały kręgu lendzielsko-polgarskiego ze st. 5 w Modlnicy, pow. krakowski. In: Kruk J., Zastawny A. (Eds), Modlnica, st. 5: Od neolitu środkowego do wczesnej epoki brązu. Via Archaeologica. Kraków: 95-172.

Inizan M.-L., Reduron-Ballinger M., Roche H., Tixier J., 1999. Technology and Terminology of Knapped Stone. Meudon: CREP, Nanterre.

JACOMET S., 2006. Identification of cereal remains from archaeological sites. University of Basel. Basel.

Kaczanowska M., KozŁowski J. K. 1976. Studia nad surowcami krzemiennymi południowej części Wyżyny Krakowsko-Częstochowskiej. Acta Archaeologica Carpathica 16: 201-219.

Kapcia M., Mueller-Bieniek A., 2018. Archaeobotanical analysis of abundant cereal finds from Kraków Nowa-Huta Mogiła 62 - getting back to the old story. Folia Quaternaria 86: 217-231. DOI: 10.4467/21995923FQ.18.004.9822

Kapcia M., Mueller-Bieniek A., 2019. An insight into Bronze Age subsistence strategy in forested Carpathian foothills, based on plant macro-remains. Archaeological and Anthropological Sciences 11: 2879-2895. DOI: 10.1007/s12520-018-0720-9

KLuZIK A., 2010. Osada kultury pucharów lejkowatych w Krakowie Nowej Hucie-Mogile, stan. 62. Materiały Archeologiczne Nowej Huty 25: 7-66.

Kornaś J., Medwecka-Kornaś A., 1967. Szata roślinna Krakowa. Acta Geographica. Series GeographicaPhysica I: 149-163.

Kotynia K., 2016. Gospodarka roślinna na osadzie KPL w Mozgawie (stanowiska 1-3) na tle danych z południowo-wschodniej grupy kultury pucharów lejkowatych (MA thesis). Jagiellonian University. Kraków.

Kozıowski J. K., 2006. Grupa Wyciąże-Złotniki i bezpośrednie oddziaływania późnopolgarskie. In: Kaczanowska M. (Ed.), Dziedzictwo cywilizacji naddunajskich: Małopolska na przełomie epoki kamienia i miedzi. Kraków: 53-62.

Kozıowski J.K., Van Vliet B., Sachse-Kozlowska E., Kubiak H., Zakrzewska G., 1974. Upper Paleolithic site with dwellings of mammoth bones - Cracow, Spadzista street B. Folia Quaternaria 44: 1-110.

Kruk J., LityŃSka-ZająC M., Milisauskas S., 2016. Gospodarka roślinna w neolicie. Studium przypadku / Neolithic plant cultivation at Bronocice. Institute of Archaeology and Ethnology, Polish Academy of Sciences. Kraków.

Kruk J., Milisauskas S., 2018. Bronocice. The Chronology and Development of a Neolithic Settlement of the Fourth Millennium BC. Institute of Archaeology and Ethnology, Polish Academy of Sciences. Kraków.

Kruk J., Milisauskas S., WøodarcZak P., 2018. Real Time. Radiocarbon Dates and Bayesian Analysis of the Neolithic Settlement at Bronocice, Fourth Millennium BC. Institute of Archaeology and Ethnology, Polish Academy of Sciences. Kraków.

Kulpa W., 1974. Nasionoznawstwo chwastów, 2nd ed. Państwowe Wydawnictwo Rolnicze i Leśne. Warszawa.

LiTYŃSKa-ZAJĄC M., 1997. Środowisko i uprawa roślin w czasach pra- i wczesnohistorycznych. In: Tunia K. (Ed.), Z archeologii Małopolski. Historia i stan badań zachodniomałopolskiej wyżyny lessowej. Kraków: 459-481.

LiTYŃSKA-ZAJĄC M., 2005. Chwasty w uprawach roślinnych w pradziejach i wczesnym średniowieczu. Instytut Archeologii i Etnologii Polskiej Akademii Nauk. Kraków.

LityŃSKa-ZająC M., 2007. Early Neolithic agriculture in south Poland as reconstructed from archaeobotanical plant remains. In: Colledge S., Conolly J. (Eds), The Origins and Spread of Domestic Plants in Southwest Asia and Europe. Walnut Creek: 315-326. 
Lityńska-Zając M., Czekaj-Zastawny A., Rauba-Bukowska A., 2017. Utilisation of cultivated and wild plants in the economy of the Linear Pottery culture in the Upper Vistula Basin. Sprawozdania Archeologiczne 69: 271-296. DOI: 10.23858/SA69.2017.011

LityŃSKa-Zając M., Wasylikowa K., 2005. Przewodnik do badań archeobotanicznych. Sorus. Poznań.

Marguerie D., Hunot J.-Y., 2007. Charcoal analysis and dendrology: data from archaeological sites in north-western France. Journal of Archaeological Science 34: 1417-1433.

Matuszkiewicz J. M., 2008. Potencjalna roślinność naturalna Polski [Potential natural vegetation of Poland]. Instytut Geografii i Przestrzennego Zagospodarowania PAN. Warszawa.

Milisauskas S., Kruk J., Pipes M.-L., Haduch E., 2016. Neolithic Human Burials Practices. The Interpretation of Funerary Behaviors at Bronocice. Institute of Archaeology and Ethnology, Polish Academy of Sciences. Kraków.

Mirek Z., Pį̨Kós-Mirkowa H., ZająC A., Zając M., 2002. Flowering plants and Pteridophytes of Poland. A checklist, 1st ed. Instytut Botaniki im. W. Szafera, Polska Akademia Nauk. Kraków.

Moskal-del Hoyo M., Mueller-Bieniek A., Alexandrowicz W. P., Wilczyński J., Wędzicha S., Kapcia M., PrzybyŁa M. M., 2017. The continuous persistence of open oak forests in the Miechów Upland (Poland) in the second half of the Holocene. Quaternary International 458: 14-27.

Moskal-del Hoyo M., Wachowiak M., Blanchette R. A., 2010. Preservation of fungi in charcoal. Journal of Archaeological Science 37: 2106-2116.

Moskal-del Hoyo M., Wacnik A., Alexandrowicz W. P., Stachowicz-Rybka R., Wilczyński J., WęDzicha S., SzWarczewski P., Korczyńska M., Cappenberg K., Nowak M., 2018. Open country species persisted in loess regions during the Atlantic and early Subboreal phases: new multidisciplinary data from southern Poland. Review of Palaeobotany and Palynology 253: 49-69. DOI: 10.1016/j. revpalbo.2018.03.005

Mueller-BienieK A., 2016. Archaeobotanical Materials of the Funnel Beaker Culture in the Brześć Kujawski and Osłonki Region. In: R. Grygiel, The Neolithic and Early Bronze Age in the Brześć Kujawski and Osłonki Region - Middle Neolithic and Late Neolithic: the Funnel Beaker Culture. Łódź: 753-769.

Mueller-Bieniek A., Bogucki P., Pyzel J., Kapcia M., Moskal-del Hoyo M., Nalepka D., 2019. The role of Chenopodium in the subsistence economy of pioneer agriculturalists on the northern frontier of the Linear Pottery culture in Kuyavia, central Poland. Journal of Archaeological Science 111: 105027. DOI: $10.1016 /$ j.jas.2019.105027

Mueller-Bieniek A., Kittel P., Muzolf B., Cywa K., Muzolf P., 2016. Plant macroremains from an early Neolithic site in eastern Kuyavia, central Poland. Acta Palaeobotanica 56: 79-89. DOI: 10.1515/ acpa-2016-0006

Mueller-Bieniek A., Pyzel J., Kapcia M., 2018. Chenopodium Seeds in Open-Air Archaeological Sites - How to Not Throw the Baby Out with the Bathwater. Environmental Archaeology, DOI: $10.1080 / 14614103.2018 .1536500$

Neef R., Cappers R .T. J., Bekker R. M., 2012. Digital Atlas of Economic Plants in Archaeology, Groningen Archaeological Studies. Barkhuis. Groningen.

NowaK M., 2004. Udział elementów lendzielsko-polgarskich w formowaniu się kultury pucharów lejkowatych w Małopolsce? Materiały Archeologiczne Nowej Huty 24: 121-138.

NowaK M., 2009. Drugi etap neolityzacji ziem polskich. Instytut Archeologii Uniwersytetu Jagiellońskiego. Kraków.

Nowak M., 2010. Późna faza cyklu lendzielsko-polgarskiego w zachodniej Małopolsce w świetle wyników badań wykopaliskowych w Podłężu, stanowisko 17 (powiat wielicki). Śląskie Sprawozdania Archeologiczne 52: 49-90. 
NowaK M., 2014. Późny etap rozwoju cyklu lendzielsko-polgarskiego w zachodniej Małopolsce. In: Czarniak K., Kolenda J., Markiewicz M. (Eds), Szkice neolityczne. Księga poświęcona pamięci prof. dr hab. Anny Kulczyckiej-Leciejewiczowej. Wrocław: 239-284.

NowaK M., 2015. Osady kultury ceramiki wstęgowej rytej i kultury pucharów lejkowatych na stanowisku 9 w Stanisławicach. In: Nowak M., Rodak T. (Eds), Osady z epoki kamienia oraz wczesnej epoki brązu na stanowiskach 9 i 10 w Stanisławicach, pow. bocheński: Kraków: 15-60.

NowaK M., 2017. Do 14C dates always turn into an absolute chronology? The case of the Middle Neolithic in western Lesser Poland. Documenta Praehistorica 44: 240-271.

NowaK M., 2019. The Funnel Beaker culture in western Lesser Poland: Yesterday and today. Archaeologia Polona 57: 79-101. DOI: 10.23858/APa57.2019.006

Nowak M., DzięGielewski K., Szczerba R., 2007. Late Lengyel-Polgar in Western Little Poland reflected by excavations in Podłęże near Kraków. In: Kozłowski J. K., Raczky P. (Eds), The Lengyel, Polgár and Related Cultures in the Middle/Late Neolithic in Central Europe. Kraków: 449-470.

Orton C., Tyers P., Vince A., 1993. Pottery in Archaeology. Cambridge University Press, Cambridge.

Ralska-Jasiewiczowa M., Latalowa M., Wasylikowa K., Tobolski K., Madeyska E., Wright H.E. JR., Turner CH., (Eds), 2004. Late Glacial and Holocene History of Vegetation in Poland based on Isopollen Maps. W. Szafer Institute of Botany, Polish Academy of Sciences. Kraków.

Schweingruber F. H., 1990. Anatomie Europäischer Hölzer. Paul Haupt Berne und Stuttgart Publishers. Bern-Stuttgart.

Seneta W., Dolatowski J., 2004. Dendrologia. Wydawnictwo Naukowe PWN. Warszawa:

SoвCZYK K., 2015. Kraków Spadzista site - history of the research. In: Wilczyński J. (Ed.). A Gravettian Site in Southern Poland: Jaksice II. Kraków: 5-18.

Tobolski K., Nalepka D., 2004. Fraxinus excelsior L. - Ash. In: Ralska-Jasiewiczowa M., Latałowa M., Wasylikowa K., Tobolski K., Madeyska E., Wright H.E. Jr., Turner Ch. (Eds.), Late Glacial and Holocene history of vegetation in Poland based on isopollen maps. Kraków: 105-110.

Wasylikowa K., Gluza I., LityŃsKa-Zając M., TomcZyńska Z., 1992. Charcoals from three Neolithic settlements in the loess area of south-central Poland. Bulletin de la Société Botanique de France 139. Actualités Botaniques 2/3/4: 373-382.

Wilczyński J., Goslar T., Wojtal P., Oliva P., Göhlich U.B., Antl-Weiser W., Šída P., Verpoorte A., Lengyel G., 2019. New radiocarbon dates for the Late Gravettian in Eastern Central Europe. Radiocarbon, DOI:10.1017/RDC.2019.111.

WiLCZYŃSKi J., Wojtal P., SobCZYK K., 2012. Spatial organization of the Gravettian mammoth hunters site - Kraków Spadzista (southern Poland). Journal of Archaeological Science 39: 3627-3642.

ZastaWny A., 2014. Neolityczne osadnictwo strefy „piaskowej” południowego obrzeżenia doliny Wisły pod Krakowem w świetle badań na stanowisku 13 w Kokotowie, gm. Wieliczka, woj. małopolskie. In: Kadrow S. (Ed.), Raport 2009. Warszawa: 11-52

Zastawny A., WŁodarczak P., Grabowska B., 2011. Osada kultury pucharów lejkowatych w Modlnicy, pow. krakowski. In: Kruk J. \& Zastawny A. (Eds), Modlnica, st. 5: Od neolitu środkowego do wczesnej epoki brązu. Via Archaeologica. Kraków: 231-290.

Zohary D., Hopf M., Weiss E., 2012. Domestication of plants in the Old World, 4th ed. Oxford University Press. Oxford. 